\title{
PEMBELAJARAN INKUIRI TERBIMBING BERBASIS PRAKTIKUM PADA TOPIK LAJU REAKSI
}

\author{
Tri Sundari $^{1)}$, Indarini Dwi Pursitasari ${ }^{2)}$, Leny Heliawati ${ }^{3)}$ \\ ${ }^{1)}$ SMA Kosgoro Bogor \\ ${ }^{2)}$ Prodi Pendidikan IPA PPs Universitas Pakuan \\ ${ }^{3)}$ Prodi Pendidikan IPA PPs Universitas Pakuan
}

\begin{abstract}
This study aims to investigate the influence of learning guided inquiry based on practicum on the rate of reaction to mastery of concepts and students' scientific attitudes. The research was conducted in one of the private high schools in Bogor City class XI IPA in the academic year 2016/2017. The population was 192 students with the total sample of 60 students divided into 31 students following the guided inquiry based learning and 29 students followed the traditional learning. The data collection is done through the test of mastery of the concept of reaction rate and the questionnaire of scientific attitude with Likert scale. Data were analyzed statistically descriptive and inferential using independent t-test. The results showed that there was a significant difference between the mastery of students 'concepts that followed the guided inquiry learning based on practice (average 80.7) and the mastery of students' concepts following traditional learning (average 74.8). Students 'scientific attitudes also showed significant differences between students who followed learning with guided inquiry based on practice (average 3.2) and students' scientific attitudes following traditional learning (average 2.2). Thus it can be concluded that guided inquiry learning based on practice can improve the mastery of students' scientific concepts and attitudes.
\end{abstract}

Key Words : Guided inquiry, practicum, conceptual mastery, and scientific attitude

\begin{abstract}
Abstrak: Penelitian ini bertujuan menyelidiki pengaruh pembelajaran inkuiri terbimbing berbasis praktikum pada materi laju reaksi terhadap penguasaan konsep dan sikap ilmiah siswa. Penelitian dilaksanakan di salah satu SMA swasta di Kota Bogor kelas XI IPA pada tahun ajaran 2016/2017. Populasi berjumlah 192 siswa dengan jumlah sampel sebanyak 60 siswa yang dibagi ke dalam 31 siswa mengikuti pembelajaran inkuiri terbimbing berbasis praktikum dan 29 siswa mengikuti pembelajaran tradisional. Pengumpulan data dilakukan melalui test penguasaan konsep laju reaksi dan angket sikap ilmiah dengan skala likert. Data dianalisis secara statistik deskriptif dan inferensial menggunakan independent t-test. Hasil penelitian menunjukkan terdapat perbedaan yang signifikan antara penguasaan konsep siswa yang mengikuti pembelajaran inkuiri terbimbing berbasis praktikum (rata-rata 80,7) dan penguasaan konsep siswa yang mengikuti pembelajaran tradisional (rata-rata 74,8). Sikap ilmiah siswa juga menunjukkan perbedaan yang signifikan antara siswa yang mengikuti pembelajaran dengan inkuiri terbimbing berbasis praktikum (rata-rata 3,2) dan sikap ilmiah siswa yang mengikuti pembelajaran tradisional (rata-rata 2,2). Dengan demikian dapat disimpulkan pembelajaran inkuiri terbimbing berbasis praktikum dapat meningkatkan penguasaan konsep dan sikap ilmiah siswa.
\end{abstract}

Kata Kunci: inkuiri terbimbing, praktikum, penguasaan konsep, dan sikap ilmiah

\section{PENDAHULUAN}

Pelajaran kimia di SMA menuntut siswa untuk memiliki sikap positif terhadap kimia dengan menyadari keteraturan dan keindahan alam serta mengagungkan kebesaran Tuhan Yang Maha Esa, memupuk sikap ilmiah, memiliki pengalaman menerapkan metode ilmiah, melalui percobaan dan eksperimen, meningkatkan kesadaran siswa tentang pentingnya kelestarian lingkungan, serta memahami konsep, prinsip, hukum, dan teori kimia serta saling keterkaitan dan penerapannya untuk menyelesaikan masalah dalam kehidupan sehari-hari dan teknologi (Badan Standar Nasional Pendidikan, 2006). Pentingnya pelajaran kimia bagi siswa memerlukan peran akif dari siswa dan guru dalam mengelola kegiatan pembelajaran.
Kenyataan di lapangan menunjukkan belum semua guru kimia memahami tujuan tersebut. Banyak guru kimia yang belum kreatif menggunakan fasilitas yang ada. Guru masih berceramah (chalk and talk), pemberian tugas, dan belum mengggunakan sarana laboratorium yang ada, sehingga siswa tidak mempunyai kesempatan untuk praktikum. Belajar secara langsung dengan praktikum akan menambah pengalaman siswa dalam memahami konsep maupun prinsip dalam kimia. Banyaknya konsep kimia yang abstrak yang harus dipelajari siswa, menyebabkan ilmu kimia merupakan salah satu pelajaran yang sulit dan membosankan bagi siswa. Oleh karena itu, guru harus merencanakan pembelajaran dengan memilih model, pendekatan, strategi, maupun metode yang 
sesuai dengan karakteristik materi pelajaran agar pembelajaran lebih menyenangkan dan bermakna.

Pursitasari (2009) menerapkan pendekatan kontekstual dalam pembelajaran termokimia. Hasil penelitian menunjukkan terjadi peningkatan aktivitas dan hasil belajar termokimia siswa kelas XI MAN Alkhaerat Kota Palu. Pursitasari dan Aminah (2010) juga telah mengembangkan buku ajar berorientasi Contextual Teaching and Learning untuk meningkatkan hasil belajar siswa SMA di kota Palu. Hasil penelitian menunjukkan pembelajaran menjadi lebih efektif sehingga hasil belajar siswa lebih baik. Meskipun terjadi peningkatan hasil belajar, namun belum mengembangkan keterampilan proses sains dan sikap ilmiah siswa.

Salah satu model pembelajaran yang bersifat student centered serta memberikan kesempatan yang seluas-luasnya kepada siswa untuk mengembangkan aktivitas hands-on dan minds-on adalah pembelajaran inkuiri. Pembelajaran inkuiri memberikan kesempatan kepada siswa untuk mengajukan pertanyaan, mengajukan hipotesis, mencari informasi, melakukan penyelidikan, melakukan pengamatan, mencatat dan mengolah data, serta menyajikannya dalam laporan. Pembelajaran inkuiri juga menuntut siswa untuk tidak hanya menghafal materi pelajaran, namun siswa harus mampu memaknai pengetahuan yang diperolehnya dan melatih kemampuan berpikir siswa.

Proses inkuiri dilakukan dengan membiasakan siswa berpikir kritis dengan mengamati, membuat pertanyaan, merumuskan hipotesis, membuat prediksi, merencanakan inkuiri untuk menyelesaikan problem, melakukan pengukuran yang cermat dan teliti, menafsirkan perolehan data, membuat kesimpulan, memahami keterbatasan penelitian ilmiah, dan mengerti bagaimana pengetahuan dapat dicapai dan diaplikasikan untuk menyelesaikan masalah yang dihadapi (Minner et al., 2010). Pembelajaran berbasis inkuiri dalam perspektif sains melibatkan siswa dalam proses sains. Keterlibatan siswa dalam proses sains sesuai dengan hakikat sains yaitu sains sebagai proses, produk, dan sikap. Menurut teori konstruktivisme, pengetahuan dibangun melalui partisipasi dan keterlibatan siswa dalam pembelajaran. Siswa menafsirkan dan membangun pengetahuannya sendiri berdasarkan masalah yang dihadapi, pengalaman menyelesaikan masalah dan interaksi sosial.
Pembelajaran inkuiri terbukti dapat meningkatkan rasa percaya diri, mendorong ketertarikan siswa mempelajari fisika, serta dapat meningkatkan prestasi belajar siswa dalam mata pelajaran fisika (Aksela \& Boström, 2012, Kholifudin, 2012). Model inkuiri terbimbing juga dapat meningkatkan hasil belajar siswa (Abdelraheem \& Asan, 2006), literasi sains dan percaya diri siswa (Gormally et al., 2009), kerja ilmiah siswa (Ariesta \& Supartono, 2011), serta penguasaan konsep, motivasi siswa (Bayram et al., 2013), dan konservasi karakter (Sarwi et al.. 2016).

Pembelajaran inkuiri dapat dilaksanakan di kelas maupun laboratorium. Laboratorium berperan penting dalam pengembangan sains. Hasil penelitian Sheppard (2006) dan Orgill \& Sutherland (2008) menunjukkan siswa sangat kesulitan dalam memahami ilmu kimia karena pembelajaran cenderung bersifat teoritis, berpusat pada guru, terlalu bergantung pada buku ajar, serta kurang melibatkan siswa dalam aktivitas laboratorium. Pembelajaran bermakna dapat terjadi di laboratorium jika siswa memiliki peluang memanipulasi peralatan dan bahan-bahan yang ada di lingkungan sekitarnya untuk membangun pengetahuan berdasarkan fenomena dan keterkaitan konsep-konsep sains (Hofstein \& Lunetta, 2003).

Penelitian tentang pembelajaran yang berlangsung di laboratorium telah dilakukan Kelly \& Finlayson (2008) yang menyimpulkan pembelajaran berbasis masalah di laboratorium memberikan kesempatan yang lebih luas kepada peserta didik untuk melakukan pengembangan keterampilan, pemahaman konsep dan proses eksperimen. Hasil penelitian Cooper dan Kerns (2006) perubahan kegiatan laboratorium sederhana ke laboratorium kooperatif memberikan kesempatan kepada mahasiswa untuk bebas bereksperimen dan membuat keputusan tentang apa, bagaimana, dan mengapa melakukan aktivitas eksperimen, memiliki kemampuan problem solving, memiliki pemahaman yang mendalam, dan lebih kreatif. Dalam hal ini asisten laboratorium lebih banyak berperan sebagai pengarah atau fasilitator.

Berdasarkan hasil-hasil penelitian tersebut, maka perlu dilakukan penelitian dengan menerapkan pembelajaran inkuiri berbasis praktikum pada pelajaran kimia di sebuah sekolah swasta di kota Bogor. Tujuan penelitian adalah menyelidiki 
pengaruh pembelajaran inkuiri terbimbing berbasis praktikum pada materi laju reaksi terhadap penguasaan konsep dan sikap ilmiah siswa.

\section{METODE}

Penelitian ini dilakukan di salah satu sekolah swasta di kota Bogor. SMA Penelitian quasy experiments ini dilakukan di kelas XI pada materi laju reaksi. Kelas XI IPA 3 sebagai kelas eksperimen dan kelas XI IPA 4 sebagai kelas kontrol. Kelas eksperimen mengikuti pembelajaran inkuiri terbimbing berbasis praktikum, sedangkan kelas kontrol menggunakan ceramah dan praktikum (tradisional). Kedua kelas diberikan pre test dan post test. Pada akhir pembelajaran diberikan angket sikap ilmiah pada kedua kelas untuk mengukur sikap ilmiah siswa dan diberikan angket tanggapan siswa terhadap pembelajaran.

Pengumpulan data menggunakan tes penguasaan konsep berupa 20 butir pilihan ganda yang valid dengan koefisien reliabilitas sebesar 0,812 dan lima soal uraian. Data sikap ilmiah diperoleh dari angket dengan skala Likert berjumlah 20 butir dengan 4 pilihan jawaban yaitu sangat setuju, setuju, tidak setuju, dan sangat tidak setuju. Tanggapan siswa terhadap penerapan pembelajaran inkuiri terbimbing pada materi laju reaksi diperoleh dari hasil kuisioner yang dibagikan pada akhir pembelajaran. Analisis data dilakukan secara desktiptif dan inferensial menggunakan uji-t independet karena data terdistribusi normal dan homogen.

\section{HASIL DAN PEMBAHASAN \\ Penguasaan Konsep Siswa}

Kegiatan penelitian diawali dengan melakukan pre test pada kelas kontrol dan kelas eksperimen. Selanjutnya kelas eksperimen diberi perlakuan dengan menggunakan model pembelajaran inkuiri terbimbing berbasis praktikum serta kelas kontrol dengan menggunakan pembelajaran tradisional. Variabel yang diukur dalam penelitian ini adalah penguasaan konsep dan sikap ilmiah.
Deskripsi data penguasaan konsep siswa dapat dilihat pada Tabel 1.

Tabel 1. Diskripsi Hasil Penguasaan Konsep Siswa

\begin{tabular}{lcc}
\hline \multicolumn{1}{c}{ Parameter } & Tradisional & $\begin{array}{c}\text { Inkuiri } \\
\text { Terbimbing } \\
\text { berbasis } \\
\text { praktikum }\end{array}$ \\
\hline $\begin{array}{l}\text { Jumlah siswa } \\
\begin{array}{l}\text { Nilai minimum } \\
\text { Nilai }\end{array}\end{array}$ & 29 & 31 \\
$\begin{array}{l}\text { maksimum } \\
\text { Rata-rata }\end{array}$ & 60 & 60 \\
$\begin{array}{l}\text { Simpangan } \\
\text { baku }\end{array}$ & 74,8 & 95 \\
$\begin{array}{l}\text { Varians } \\
\text { Rata-rata } \\
\text { gain }(\%)\end{array}$ & 7,9 & 80,7 \\
Kategori N-gain & 63,9 & 7,7 \\
& 63,7 & 75,8 \\
\hline
\end{tabular}

Tabel 1 menunjukkan rata-rata dan $\mathrm{N}$-gain penguasaan konsep siswa pada materi laju reaksi dengan pembelajaran inkuiri terbimbing berbasis praktikum lebih besar daripada di kelas tradisional. Hasil uji signifikansi perbedaan rata-rata penguasaan konsep di kelas eksperimen dan kontrol menunjukkan nilai $t_{\text {hitung }}$ sebesar 2,444. dan nilai Sig (2-tailed) sebesar 0,018. Jika dibandingkan dengan $t_{\text {tabel }}$ sebesar 2,002, maka nilai $t_{\text {hitung }}$ lebih besar daripada $t_{\text {tabel }}$ sehingga hipotesis nol yang menyatakan tidak ada perbedaan rata-rata penguasaan konsep siswa menggunakan inkuiri terbimbing berbasis praktikum dan pembelajaran tradisional ditolak. Hal ini berarti hipotesis alternatif diterima, sehingga dapat disimpulkan terdapat perbedaan yang signifikan ratarata penguasaan konsep siswa menggunakan inkuiri terbimbing berbasis praktikum dan pembelajaran tradisional pada tingkat signifikansi 0,05 . Peninjauan lebih lanjut terhadap peningkatan penguasaan konsep siswa pada setiap sub materi laju reaksi terdapat pada Gambar 1. 


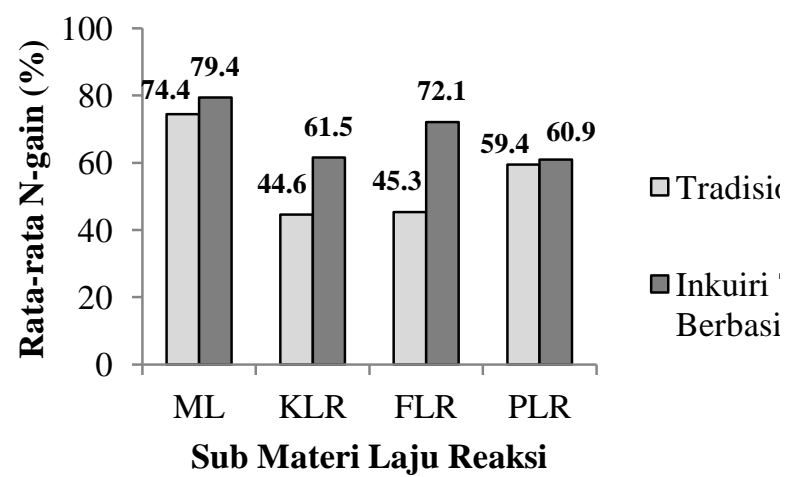

Gambar 1. Rata-rata N-Gain Setiap Sub Materi Laju Reaksi

\section{Keterangan:}

ML : molaritas larutan, KLR: konsep laju reaksi, FLR : faktor laju reaksi, dan PLR: persamaan laju reaksi

Gambar 1 menunjukkan rerata N-gain penguasaan konsep siswa di setiap sub materi laju reaksi di kelas yang mengikuti pembelajaran inkuiri terbimbing berbasis praktikum lebih besar daripada pembelajaran tradisional, kecuali pada sub materi persamaan laju reaksi. Peningkatan penguasaan konsep tertinggi terdapat pada sub materi molaritas larutan dengan kategori tinggi dan terendah sub materi konsep laju reaksi dengan kategori sedang. Peningkatan penguasaan konsep jika ditinjau dari aspek kognitif berdasarkan dimensi kognitif pada taksonomi Bloom ditunjukkan pada Gambar 2.

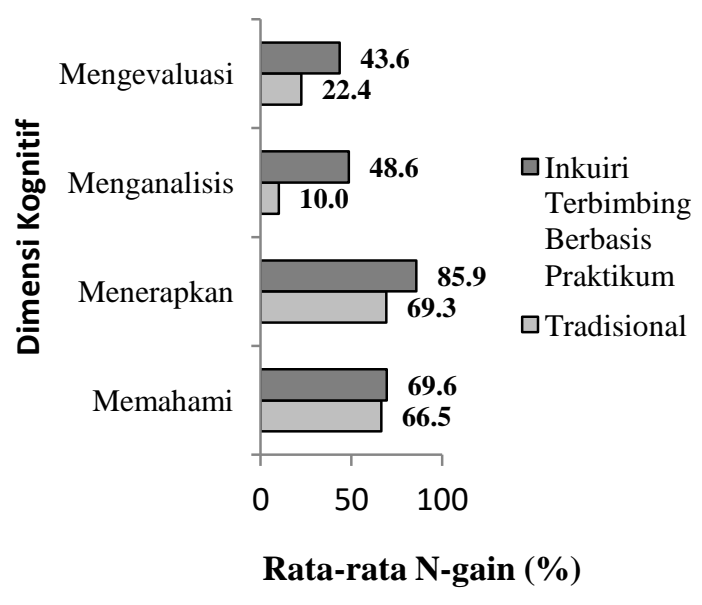

Gambar 2. Rerata N-gain Penguasaan Konsep Siswa Berdasarkan Dimensi Kognitif

Gambar 2 menunjukkan rata-rata N-Gain pada seluruh dimensi kognitif di kelas inkuiri terbimbing berbasis praktikum lebih besar dari pada kelas tradisional. Rerata N-gain tertinggi terdapat pada kemampuan menerapkan di kelas inkuiri terbimbing berbasis praktikum dan terendah adalah kemampuan menganalisis di kelas tradisional.

\section{Sikap Ilmiah}

Pembelajaran inkuiri berbasis praktikum selain dapat meningkatkan penguasaan konsep siswa pada laju reaksi juga mampu membangun sikap ilmiah siswa. Hasil perolehan sikap ilmiah siswa setelah pembelajaran kimia pada materi laju reaksi baik di kelas inkuiri terbimbing berbasis praktikum maupun kelas tradisional terdapat pada Tabel 2.

Tabel 2 menunjukkan sikap ilmiah siswa di kelas inkuiri terbimbing berbasis praktikum (rata-rata 3,2 dengan kategori baik) lebih besar daripada di kelas tradisional (rata-rata 2,2 dengan kategori cukup). Hal ini berarti siswa yang mengikuti pembelajaran inkuiri terbimbing berbasis praktikum memiliki sikap ilmiah dengan kategori baik.

Tabel 2. Diskripsi Data Sikap Ilmiah Siswa

\begin{tabular}{lcc}
\hline \multicolumn{1}{c}{ Parameter } & Tradisional & $\begin{array}{c}\text { Inkuiri } \\
\text { Terbimbing } \\
\text { berbasis } \\
\text { praktikum }\end{array}$ \\
\hline Jumlah siswa & 29 & 31 \\
Skor minimum & 2.3 & 2.8 \\
Skor & 3.6 & 3.9 \\
maksimum & & \\
Jumlah & 83.0 & 100.6 \\
\hline
\end{tabular}




\begin{tabular}{lcc}
\hline Rata-rata & 2.2 & 3.2 \\
Simpangan & 0.4 & 0.3 \\
baku & & \\
Varians & 0.16 & 0,09 \\
\hline
\end{tabular}

Uji signifikansi perbedaan sikap ilmiah siswa yang mengikuti pembelajaran inkuiri terbimbing berbasis praktikum dan pembelajaran tradisional menunjukkan nilai $t_{\text {htung }}(4,467)$ lebih besar daripada $\mathrm{t}_{\text {tabel }}(2,002)$ pada tingkat signifikansi 0,05 . Hal ini berarti terdapat perbedaan yang signifikan antara sikap ilmiah siswa yang mengikuti pembelajaran inkuiri terbimbing dan pembelajaran tradisional.

Aspek sikap ilmiah yang muncul melalui pembelajaran inkuiri terbimbing berbasis praktikum adalah jujur, teliti, rasa ingin tahu, terbuka, disiplin, dan tanggung jawab. Perolehan hasil angket sikap ilmiah pada setiap aspek terdapat pada Gambar 3.

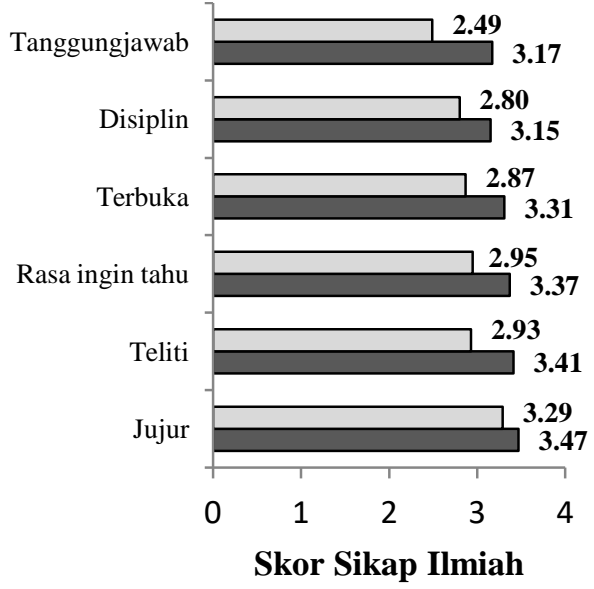

Gambar 3. Hasil Sikap Ilmiah pada Setiap Aspek

Gambar 3 menunjukkan sikap ilmiah siswa pada setiap aspek setelah mengikuti pembelajaran inkuiri terbimbing berbasis praktikum lebih baik daripada sikap ilmiah siswa di kelas tradisional. Skor sikap ilmiah tertinggi adalah kejujuran dan skor terendah adalah tanggung jawab.

\section{Pembahasan}

Pembelajaran inkuiri terbimbing berbasis praktikum memberikan kesempatan kepada siswa untuk belajar secara aktif. Siswa dapat mencari sumber belajar sendiri baik lewat buku maupun internet. Guru berperan sebagai fasilitator dan memberikan bimbingan kepada siswa yang mengalami kesulitan dalam membangun pengetahuan. Kegiatan pembelajaran yang dilakukan siswa ini akan lebih bermakna sehingga akan tersimpan dalam memori jangka panjang.

Peningkatan penguasaan konsep siswa berdasarkan rata-rata $\mathrm{N}$-gain untuk siswa yang mengikuti pembelajaran tradisional sebesar $63,7 \%$ atau 0.64 dengan kategori sedang. Adapun rata-rata $\mathrm{N}$-gain penguasaan konseo siswa yang mengikuti pembelajaran inkuiri berbasis praktikum sebesar $75,8 \%$ atau 0,76 dengan kategori tinggi. Hal ini menunjukkan bahwa pembelajaran inkuiri terbimbing berbasis praktikum memberikan peningkatan penguasaan konsep yang lebih besar.

Pembelajaran inkuiri terbimbing yang dirangkaikan kegiatan praktikum di laboratorium pada materi laju reaksi menjadikan siswa lebih bersemangat dan termotivasi sehingga penguasaan konsep juga meningkat. Hal ini senada dengan hasil penelitian Bayran, et al. (2013) bahwa pembelajaran inkuiri dapat meningkatkan motivasi dan hasil belajar siswa.

Peningkatan penguasaan konsep yang dihasilkan dalam pembelajaran berbasis praktikum dikarenakan selama proses pembelajaran siswa dilatih melalui tahapan sebagai berikut: siswa mengidentifikasi permasalahan yang dihadapi dalam laju reaksi. Identifikasi masalah penting dilakukan agar peserta didik dapat merumuskan permasalahan secara jelas.Selanjutnya siswa mencari referensi dari berbagai sumber untuk menyelesaikan problem yang dihadapi dengan membuat perencanaan.Saat mencari referensi siswa mendapatkan banyak informasi dari berbagai sumber, melakukan analisis, dan sintesis.Pencarian pengetahuan tersebut menjadikan perolehan pengetahuan siswa menjadi lebih bermakna.Tahap implementasi perencanaan solusi dilakukan melalui praktikum di laboratorium dibawah bimbingan dan pengawasan guru.

Menurut Aktamis dan Acar (2010), pembelajaran praktikum di laboratorium menyebabkan pembelajar mampu mengembangkan keterampilan pengaturan diri. Proses pengaturan diri ini sangat penting dalam pembelajaran. Tarhan dan Sesen (2010) juga menyimpulkan bahwa pembelajaran dengan praktikum di laboratorium dapat meningkatkan prestasi belajar dan sikap terhadap laboratorium. Selama ini laboratorium kimia jarang digunakan dalam pembelajaran di SMA swasta di kota Bogor. Padahal menurut Hofstein dan 
Lunetta (2003) bahwa pembelajaran di laboratorium dapat terjadi melalui manipulasi peralatan dan bahanbahan yang ada di lingkungan sekitarnya berdasarkan fenomena dan keterkaitan konsep-konsep.Kegiatan tersebut dapat meningkatkan kemampuan siswa.

Peninjauan lebih lanjut hasil penguasaan konsep pada setiap sub materi menunjukkan sub materi molaritas memiliki peningkatan tertinggi baik dikelas tradisional maupun kelas inkuiri br, Pada materi molaritas ini, di dalam praktikum siswa melakukan sendiri membuat larutan dan mengencerkan larutan, sehingga siswa lebih mudah mengingatnya dalam mengerjakan soal-soal molaritas. Materi molaritas larutan pernah diajarkan di kelas X, hal ini menyebabkan tidak ada perbedaan yang signifikan antara kelas kontrol dan kelas eksperimen. Namun secara umum peningkatan penguasaan konsep lebih baik dari pada kelas tradisional, meskipun pada persamaan laju reaksi dan molaritas larutan perbedaannya tidak terlalu besar.Hal ini berimplikasi perlunya latihan soal yang lebih banyak agar siswa lebih memahaminya. Dari hasil penelitian menunjukkan pembelajaran inkuiri terbimbing dapat meningkatkan penguasaan konsep siswa baik secara keseluruhan maupun pada setiap sub materi.

Kemampuan siswa di kelas inkuiri terbimbing berbasis praktikum dalam menerapkan pengetahuan memperoleh nilai $\mathrm{N}$-gain terbesar yaitu $85,9 \%$ atau 0,86 , namun kemampuan mengevaluasi siswa masih rendah dengan $\mathrm{N}$-gain sebesar $43,6 \%$ atau 0,44 . Rendahnya kemampuan menganalisis disebabkan siswa belum terbiasa melakukan evaluasi ketika menyelesaikan problem yang dihadapinya.

Pembelajaran inkuiri memberikan kesempatan kepada siswa untuk terlibat secara langsung dalam proses belajar. Guru memberikan suatu masalah untuk dipecahkan sendiri oleh siswa. Guru berperan sebagai pembimbing dan motivator. Siswa dilatih untuk mencari sumber sendiri baik dari internet maupun buku. Siswa juga dapat bekerjasama dalam kelompoknya untuk berdiskusi, merumuskan masalah, mengumpulkan data, menarik kesimpulan dan menyampaikan hasil.

Pada saat aktivitas inkuiri, siswa dilatih untuk mengembangkan kemampuannya untuk menjelaskan atau mengemukakan reaksi yang terjadi, dan menentukan persamaan laju reaksi melalui fenomena ilmiah. Klahr et al. (Varma, 2014) juga mengungkapkan bahwa kebiasaan siswa untuk mengungkapkan bukti dan alasan secara logis dapat dilatihkan melalui kegiatan inkuiri.

Kegiatan praktikum dalam pembelajaran inkuiri terbimbing berbasis praktikum juga memberikan kesempatan kepada siswa untuk mengontrol variabel, merancang eksperimen, menganalisa hasil dan menginterprestasikan data. Hal ini dapat melatih siswa untuk bernalar. Chen dan She (2014) menyatakan kemampuan bernalar melibatkan seluruh kegiatan inkuiri seperti mengajukan pertanyaan ilmiah, mengontrol variabel, merencanakan suatu cara untuk menjawab pertanyaan, merancang eksperimen untuk menguji hipotesis, mengolah dan menganalisa data, dan mengiterprestasikan data.

Pembelajaran inkuiri terbimbing berbasis praktikum selain dapat melatih kemampuan untuk bernalar, juga dapat menimbulkan sikap ilmiah bagi siswa seperti jujur dalam mengemukakan hasil eksperimen, terbuka dalam menerima perbedaan pendapat dan pengetahuan baru, teliti dalam menyiapkan alat dan bahan serta melakukan eksperimen, disiplin dalam menyelesaikan masalah yang dihadapi dengan penuh tanggung jawab. Dengan demikian pembelajaran inkuiri berbasis praktikum pada materi laju reaksi dapat menimbulkan sikap ilmiah seperti jujur, teliti, terbuka, disiplin, sikap ingin tahu dan tanggung jawab

Dalam penelitian ini dilakukan kegiatan tes sikap ilmiah berupa angket skala Likert, yang bertujuan untuk memberikan gambaran mengenai sikap ilmiah siswa pada kelas tradisional dan pembelajaran inkuiri terbimbing berbasis praktikum. Hasil uji hipotesis menunjukkan bahwa ada perbedaan sikap ilmiah siswa di kelas tradisional dan pembelajaran inkuiri terbimbing berbasis praktikum. Sikap ilmiah siswa di kelas pembelajaran inkuiri terbimbing berbasis praktikum lebih baik daripada sikap ilmiah siswa di kelas tradisional. Perolehan nilai sikap ilmiah tertinggi pada indikator jujur baik kelompok kontrol maupun kelompok eksperimen, sikap ini perlu dijaga mengingat kejujuran sangat penting dalam sikap ilmiah, seperti jujur dalam melaporkan hasil praktikum. Sikap tanggung jawab memperoleh nilai terendah dari aspek yang lainnya, hal ini perlu adanya penekanan belajar lebih lanjut dari aspek tanggung jawab. 


\section{KESIMPULAN}

Pembelajaran inkuiri terbimbing berbasis praktikum dapat diterapkan pada pembelajaran materi laju reaksi.Pembelajaran inkuiri terbimbing melibatkan siswa untuk melakukan pengamatan langsung dengan melakukan praktikum di laboratorium, sehingga konsep yang dipelajari dapat dikuasai dengan lebih baik. Berdasarkan hasil penelitian dapat disimpulkan sebagai berikut:

1. Terdapat peningkatan penguasaan konsep siswa yang mengikuti pembelajaran inkuiri terbimbing berbasis praktikum.

2. Ada perbedaan sikap ilmiah siswa antara siswa yang mengikuti pembelajaran inkuiri terbimbing berbasis praktikum dengan siswa yang mengikuti pembelajaran tradisional.

3. Siswa memberikan tanggapan positif terhadap pembelajaran inkuiri terbimbing berbasis praktikum.

\section{SARAN}

Berdasarkan hasil penelitian yang, maka beberapa hal yang dapat disarankan yaitu:

1. Guru bidang studi kimia hendaknya menggunakan model/metode pembelajaran inovatif untuk mengajarkan konsep-konsep kimia agar siswa lebih mudah memahami materi.

2. Guru sebaiknya memperhatikan karakteristik setiap materi pada waktu menyusun rangcangan program pemelajaran pm sehingga metode yang diajarkan sesuai.

3. Materi kimia laju reaksi memerlukan kegiatan praktikum dilaboratorium, siswa dapat berinteraksi langsung dengan sumber materi, sehingga pengetahuan yang diperoleh siswa lebih bermakna.

4. Penelititian ini dapat digunakan sebagai acuan melakukan penelitian yang sama, namun perlu dipadukan dengan metode pembelajaran yang lain.

\section{DAFTAR PUSTAKA}

Abdelraheem, A. Y. \& Asan, A. 2006. The Effectiveness of Inquiry-Based Technology Enhanced Collaborative Learning Environment. International Journal of
Technology in Teaching and Learning, 2(2), 65-87.

Aksela, M. \& Boström, M. 2012. Supporting Students' Interest through Inquiry-Based Learning in the Context of Fuel Cells. Mevlana International Journal of Education (MIJE). 2(3): 53-61

Aktamis, H \& Acar, E. 2010. The Effect of "Laboratory Practices in science teaching" Course on Development of Prospective science Teachers' Self-Regulation Skills. . Procedia Social and Behavioral Sciences: 5549-5553

Ariesta, R. \& Supartono. 2011. Pengembangan Perangkat Perkuliahan Kegiatan Laboratorium Fisika Dasar II Berbasis Inkuiri Terbimbing. Jurnal Pendidikan Fisika Indonesia. 7: 62-68

Badan Standar Nasional Pendidikan. 2006. Panduan Umum KTSP. Kemendikbud

Bayram, Oskay, Erdem, \& Ozgur. 2013. Effect of inquiry based learning method on students' Motivation. Procedia Social and Behavioral Sciences 106: 988-996.

Chen, C,T \& She, H.C. 2014. The Effectiveness of Scientific Inquiry with/without Integration of Scientific Reasoning.International Journal of Science and Mathematics Education.

Cooper, M. M. \& Kerns, T. S. (2006). "Changing the Laboratoty: Effects of a Laboratory Course on Students' Attititudes and Perception". Journal of Chemical Education. 83, (9), 1356-1361.

Gormally, C., Brickman, P., Hallar, B., \& Armstrong, N. 2009. Effects of Inquiry-based Learning on Students' Science Literacy Skills and Confidence. International Journal for the Scholarship of Teaching and Learning. 3(2): $1-22$

Hofstein, A. \& Lunetta, V. N. 2003. The Laboratory in Science Education: Foundations for the Twenty-First Century. New York: Wiley Periodicals, Inc.

Kelly, O. \& Finlayson, O. (2008). “A Hurdle Too High? Students' Experience of a PBL Laboratory Module". Chemistry Education Research and Practice., 10, 42-52.

Kholifudin, M. Y. 2012. Pembelajaran Fisika dengan Inkuiri Terbimbing Melalui Metode Eksperimen dan Demonstrasi Ditinjau dari Gaya Belajar Siswa. Prosiding Pertemuan 
Ilmiah XXVI HFI Jateng \& DIY, Purworejo 14 April 2012.

Minner, D. D., Levy, A. J. \& Century, J. 2010. Inquiry-Based Science Instruction - What Is It and Does it Matter? Results from a Research Synthesis Year 1984 to 2002. Journal of Research in Science Teaching, 47 (4): 474-496.

Orgill, M. \& Sutherland, A. (2008). "Undergraduate Chemistry Students' Perception of and Misconception about Buffers and Problem Buffers". Chemical Education Reserch and Practice. 9, 131-143.

Pursitasari, I. D. (2009). "Peningkatan Aktivitas dan Pemahaman Siswa dalam Pembelajaran Kimia melalui Pendekatan Kontekstual”. Jurnal Ilmu Pendidikan. 16. (3): 172-177

Pursitasari, I., \& Aminah, S. 2010. Pengembangan Buku Ajar Berorientasi CTL untuk Meningkatkan Efektivitas Pembelajaran Kimia di SMA kota Palu. Laporan Penelitian Hibah Bersaing: Palu, tidak dipublikasikan

Sarwi, Sutardi, \& Prayitno, W. W. 2016. Implementasi Pembelajaran Fisika Guided Inquiry untuk Meningkatkan Penguasaan Konsep dan Pengembangan Karakter Konservasi Siswa. Jurnal Pendidikan Fisika Indonesia 12 (1): 1-7

Sheppard, K. (2006). "High School Students' Understanding of Titrations and Related AcidBase Phenomena". Chemical Education of Research and Practice, 7, (1), 32-45.

Tarhan, L. \& Sesen.2010. Investigation the effectiveness of laboratory works related to "acid and bases" on learning achievements and attitudes toward laboratory. International Journal Science Education. Procedia Social and BehavioralSciences 2: 2631-2636

Varma, K. 2014. Supporting Scientific Experiments and Reasoning in Young Elementary School Students. Journal of science Education and Technology. 23: 381-397. 